\title{
REARRANGEMENT OF ADMINISTRATIVE BOUNDARIES FOR REDUCING INNER-CITY DISPARITY: CASE STUDY OF TANJUNG PINANG CITY, INDONESIA
}

\author{
Adjie PAMUNGKAS \\ ITS Surabaya, Indonesia
}

\begin{abstract}
An imbalance in development between islands in Tanjung Pinang City causes inner-city disparities due to insufficient development strategies, lack of public infrastructure and remoteness of islands. On the other hand, properly designed administrative boundaries can reduce inner-city disparities by enabling good development strategies, prioritizing public infrastructure development, and connecting the entire area, including remoter islands. This paper discusses how to re-arrange administrative boundaries, particularly at the district and sub-district levels in order to decrease inner-city disparities. A combination method of scoring and participatory mapping is used to suggest new district delineation for the city. After considering the outputs of scoring and participatory mapping, the district boundaries were changed from four to eight and then back to six districts. The paper also proposes key development strategies to boost development in poorer districts by improving the allocation of new infrastructure investment so as to optimize the impact of new municipal and provincial government statuses bestowed on the Dompak and Senggarang Districts. In addition, we suggest that development strategies should provide adequate infrastructure to connect remoter islands in the Penyengat Sub-district to the main island.
\end{abstract}

Key Words: islands development, inner-city disparities, administrative boundaries, infrastructure investments.

\section{Introduction}

By the nature, the development should achieve three main goals that are life sustenance, selfesteem and freedom of choices (Todaro 1981). In achieving these goals, many development theories have been formulated including the growth pole theory (Perrox 1950 in Dawkins 2003, Glasson 1974). The growth pole theory is a response to the central place theory of Christaller in 1933 and Losch in 1954 (Dawkins 2003). The theory is basically about concentrating the economic growth in a certain place. Agglomeration factors leading to efficiency causes the growth poles concept to become a promising concept for development. The growth pole concepts then dominated the development processes in developing and developed countries since 1970s (Miyoshi 1997). It also includes Indonesia by concentrating the development process in the capital cities.

In fact, the growth pole theory brings imbalance development (Richardson and Richardson 1975). The imbalance development can be considered as regional disparity and, in this context, we consider it as inner-city disparity. Within the theory, backwash effect and trickling down effect (or spread effect) are the key factors for the successes of development goals via the growth pole theory (Myrdal 1957). Unfortunately, the backwash effect was stronger than the trickling down (spread) effect in many cases, including Indonesia, resulting in a wider gap of inner-city disparity since the new order era of Soeharto. Firdaus (2017) indicates a high coefficient of variation (CV - 0.93) in Indonesia, indicating a significant regional disparity. He also adds that the gap is getting wider if we compared the GDP data between 1983 and 2013 (Firdaus 2017). 
Since the imbalance development significantly arises in many cases, including Indonesia, critiques on the growth pole theory have been discussed widely. Polycentric Urban Region (PUR), which is based on the network system, is one of the theories responding to the failure of growth pole theory, which is based on the central place theory (Batten 1995, Bailey and Turok 2001, Meijers et al. 2003). Batten (1995) also adds that the concept is trying to duplicate many 'poles' in a region. The connected poles idea is also a strength in this concept for regional development (Bailey and Turok 2001). For the Indonesian context, the new municipalities and provinces is part of developing the underdeveloped area strategy. The new administrative areas with their capital cities increase the number of growth poles in Indonesia. Ones of the newest administrative boundaries are Riau Island Province and Tanjung Pinang City. Those new capital cities can potential become the new poles while forming the network system in Indonesia. Especially in the Tanjung Pinang City context, the idea to multiply the current poles in the surrounding areas is continued by proposing a new district delineation with a more number of districts compared to the existing ones. The increasing number of poles is believed to improve development in underdeveloped areas as well as to decrease inner-disparity in the municipalities.

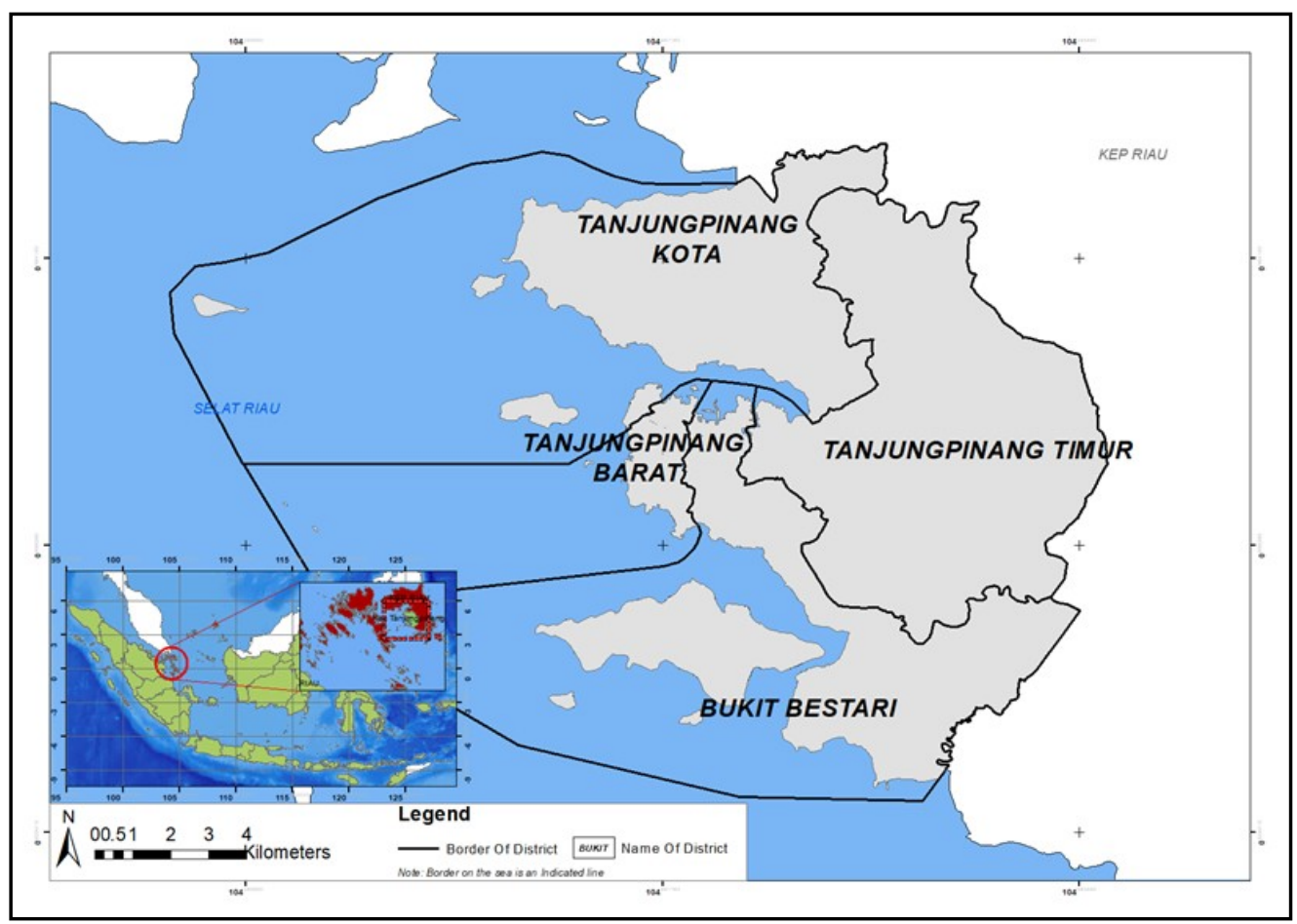

Fig. 1 - Tanjung Pinang City orientation

Source: 1. Quickbird imagery for Tanjung Pinang City in 2008; 2. Goverment Regulation No.19/2008, on District; 3. Proposal for district division 2010, Tanjung Pinang City.

Tanjung Pinang City is the capital of Indonesia's Riau Islands Province, and it was granted the city status on June 21, 2001 (Kemendagri 2013). The Province is also one of the newest in Indonesia, established on October 25, 2002 (Kemendagri 2013). Located on the main island of Bintan at $1^{\circ} 5^{\prime} 0^{\prime \prime} \mathrm{N} 104^{\circ} 29^{\prime} 0^{\prime \prime} \mathrm{E}$, the city comprises four main districts: Tanjung Pinang Kota, 
Tanjung Pinang Barat, Tanjung Pinang Timur, and Bukit Bestari. It further comprises 18 subdistricts, it covers $239.5 \mathrm{~km}^{2}$, it has 203153 inhabitants (in 2014), and the Indonesian Statistical Bureau (2015) assesses a low level of development. Figure 1 shows the location of Tanjung Pinang City in the Indonesian Archipelago and in relation to the main islands of Riau Island Province. It also illustrates the current division of districts in Tanjung Pinang City.

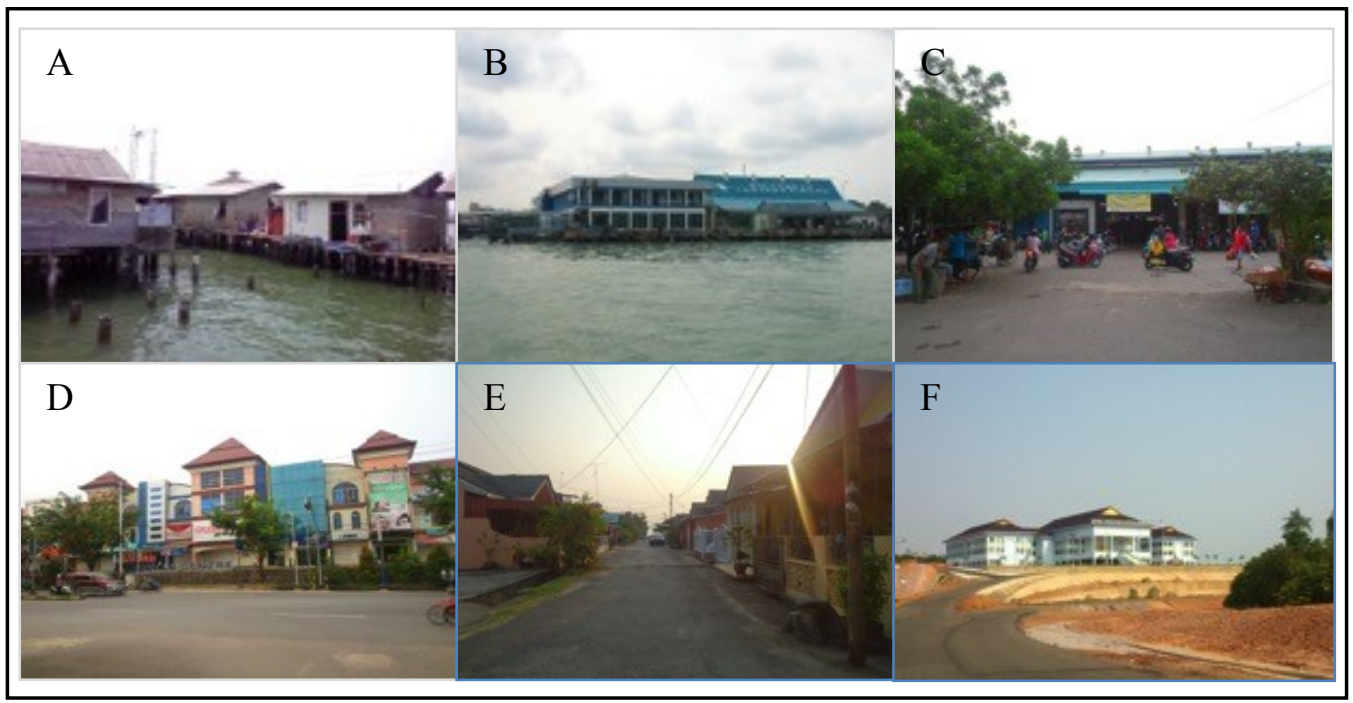

Fig. 2 - Tanjung Pinang City: A. Fisherman housing, B. Main seaport, C. Traditional market, D. Modern market, E. Densely populated housing, F. New provincial government complex

An increasing focus on coastal and marine development has directed the special attention of the government on Tanjung Pinang City as part of the islands province. The city exhibits a low level of development. Based on its statistical agency in 2015, it has a low population density (884.32 people/ $\mathrm{km}^{2}$ ); a limited number and range of city facilities such as banks, traditional non -banking facilities, shops, traditional markets, community houses, elementary, junior and senior school buildings and community health centres; a low total gross domestic product (Indonesian Rupiah - IDR 16.29 billion or USD 1.2 million), a low income per capita (IDR 14.45 million or USD 1089 annually) relative to Indonesia's averages, and the existence of many nonpermanent houses. Figure 2 provides some images of Tanjung Pinang City's facilities.

The city has also experienced unbalanced development resulting in growth disparities among its districts and sub-districts. It has been argued that low regional disparities, in our case innercity disparities, indicate a sustainable development within a region (Zuindeau 2007, Salvati et al. 2016, Yang et al. 2016). Yang et al. (2016) also add that properly designed investment can reduce regional disparities. One of the instruments to accelerate urban or economic development is the investment in infrastructure (Giang and Pheng 2011, Zeng et al. 2015, Berger and Enflo 2017), and concentrating such investment in underdeveloped city districts could potentially reduce the gap between these and the more prosperous districts. Therefore, infrastructure facilities can reflect development outputs as well as inner-city disparities. Most of these indicators reveal that sub-districts on small islands are trailing those on the main island of Tanjung Pinang City. Even there, most facilities are located mainly in three sub-districts, namely Tanjung Pinang Kota, Kemboja and Kampung Bulang. The other 15 sub-districts have poor facilities indicating the city's problem of intra-regional disparities. 
To intensify the development process and distribute the outcomes more evenly, strategies should be well designed. One of the development strategies in the Tanjung Pinang City regional spatial plan (2010-2030) is to improve the activity centers in certain service areas in a functional, hierarchical and integrated manner. Activity centers, which are the focus of public service facilities, commercial activity, industrial areas and transport infrastructure, can generate strong multiplier effects for their surrounding hinterlands. They occur in both districts and subdistricts, which are the lowest levels of government administration, and significantly influence the delivery of development in Indonesia. Careful administrative boundary delineation may create a more efficient development process and increase the impacts of development in a sustainable way (Gruby and Basurto 2013, Gaigné et al. 2016). In the long term, the arrangement of administrative boundaries is therefore one of the main factors that may accelerate a sustained economic performance (Andersson et al. 2014, Kan 2016) as well as reduce inner-city disparities. This paper proposes a strategy to determine the optimal administrative boundaries designed to achieve a balanced growth in Tanjung Pinang City. It will also elaborate key development strategies following the new arrangement of administrative boundaries at district and sub-district levels.

\section{Methodology}

We employed an innovative mixed method approach to delineate an appropriate pattern of districts and sub-districts for the delivery of government services to aid development. This approach integrated both quantitative and qualitative analyses to increase the credibility of the research. The two main sources of information were:

Indicators and Variables for Scoring the District Performance

Table 1

\begin{tabular}{|c|l|c|}
\hline Indicators & \multicolumn{1}{|c|}{ Variables } & Weight \\
\hline Population & Population size & 20 \\
\hline \multirow{2}{*}{ Size of areas } & Overall area size & 5 \\
\cline { 2 - 3 } & Effective area size - populated area & 5 \\
\hline \multirow{4}{*}{$\begin{array}{c}\text { Controlling } \\
\text { spectrum }\end{array}$} & Average distance between the populated areas and the district center & 10 \\
\cline { 2 - 3 } & Average travel time & 10 \\
\hline \multirow{5}{*}{$\begin{array}{c}\text { Availability of } \\
\text { Infrastructure }\end{array}$} & Number of banks & 2 \\
\cline { 2 - 3 } & Number of non-bank finance organizations & 2 \\
\cline { 2 - 3 } & Number of shops & 2 \\
\cline { 2 - 3 } & Number of markets & 4 \\
\cline { 2 - 3 } & Ratio of elementary graduates to total population & 4 \\
\cline { 2 - 3 } & Ratio of junior high school graduates to total population & 4 \\
\cline { 2 - 3 } & Ratio of senior high school graduates to total population & 4 \\
\cline { 2 - 3 } & Ratio of health facilities & 4 \\
\cline { 2 - 3 } & Percentage of households with electricity & 3 \\
\cline { 2 - 3 } & Ratio of length of road to number of vehicles & 3 \\
\cline { 2 - 3 } & Ratio of number of faith centers to population size & 4 \\
\cline { 2 - 3 } & Ratio of number of sports centers to population size & 3 \\
\cline { 2 - 3 } & Community halls & \\
\hline
\end{tabular}

Source: Indonesian Government Regulation No. 19/2008 
1. Scoring districts based on pre-determined variables to assess district performance, and

2. Participatory mapping to collect data and to elaborate the inter- and intra-district interaction of the inhabitants.

Crosschecking between these two data layers improved the quantity and quality of the detailed information employed and our understanding of it, thereby increasing the analytical credibility (Stewart et al. 2008, Bamberger et al. 2016, Meijering and Weitkamp 2016).

We measured each district's performance using the Indonesian Government Regulation No. $19 / 2008$ which employs five indicator categories containing 20 variables. Every variable scores from 1 (poor) to 5 (good) and it has a prescribed weight set by the regulation as shown in Table 1.

After the quantitative scoring process was completed using this approach, the districts were then classified into five ability categories on the basis of their total scores as shown in Table 2.

District Ability Classes

Table 2

\begin{tabular}{|l|l|}
\hline \multicolumn{1}{|c|}{ Score } & \multicolumn{1}{c|}{ Classification } \\
\hline $420-500$ & Very capable \\
\hline $340-419$ & Capable \\
\hline $260-339$ & Less fortunate \\
\hline $180-259$ & Incapable \\
\hline $100-179$ & Very incapable \\
\hline
\end{tabular}

Source: Indonesian Government Regulation No. 19/2008

Participatory mapping is a tool designed to explore and reveal community characteristics and to visualize them on a map. It can encourage community participation by discussing particular issues and it can also uncover the values, behaviors, preferences, ways of thinking, opinions, and attitudes of stakeholders in a case study. This social aspect is useful for enriching both planning and decision-making processes (Strickland-Munro et al. 2016). In the present study, a combination of participatory mapping and focus group discussion (FGD) was used to gain insights into community interaction within Tanjung Pinang and also to uncover the inter- and intra-district regional relations. Both strategies were conducted on 8 October 2014 with all the city's district and sub-district leaders as invitees. Participants were grouped according to their four districts of origin, making for unequal groups size. The output of participatory mapping and FGD was then interpreted in a qualitative manner to illustrate the regional and community interaction. Figure 3 illustrates the process of participatory mapping and FGD.

\section{Results and Discussion}

In 2010, the Tanjung Pinang City Mayor tried to implement the Mayoral Decree No. 45 relating to the Additional Districts to accommodate the increasing population, the imbalance in population distribution, and the fast growing infrastructures in several sub-districts. The decree stated that the existing four districts would be divided into eight districts as shown schematically in Figure 4. Some of the boundaries are notional because there are no official maps of subdistrict boundaries. In this scenario, Penyengat became a new district; Tanjung Pinang Timur was divided into two districts, namely Bandar Baru and Tanjung Pinang Timur; Tanjung Pinang Kota was divided into three districts; Tanjung Pinang Barat decreased in size due to the new delineation of Tanjung Pinang Kota; the Tanjung Pinang Kota Sub-District, together with some sub-districts from the Tanjung Pinang Barat District, became a new district called Tanjung 
Pinang Kota District; and finally, Bestari District was divided into two main districts, namely Dompak and Bukit Besari.

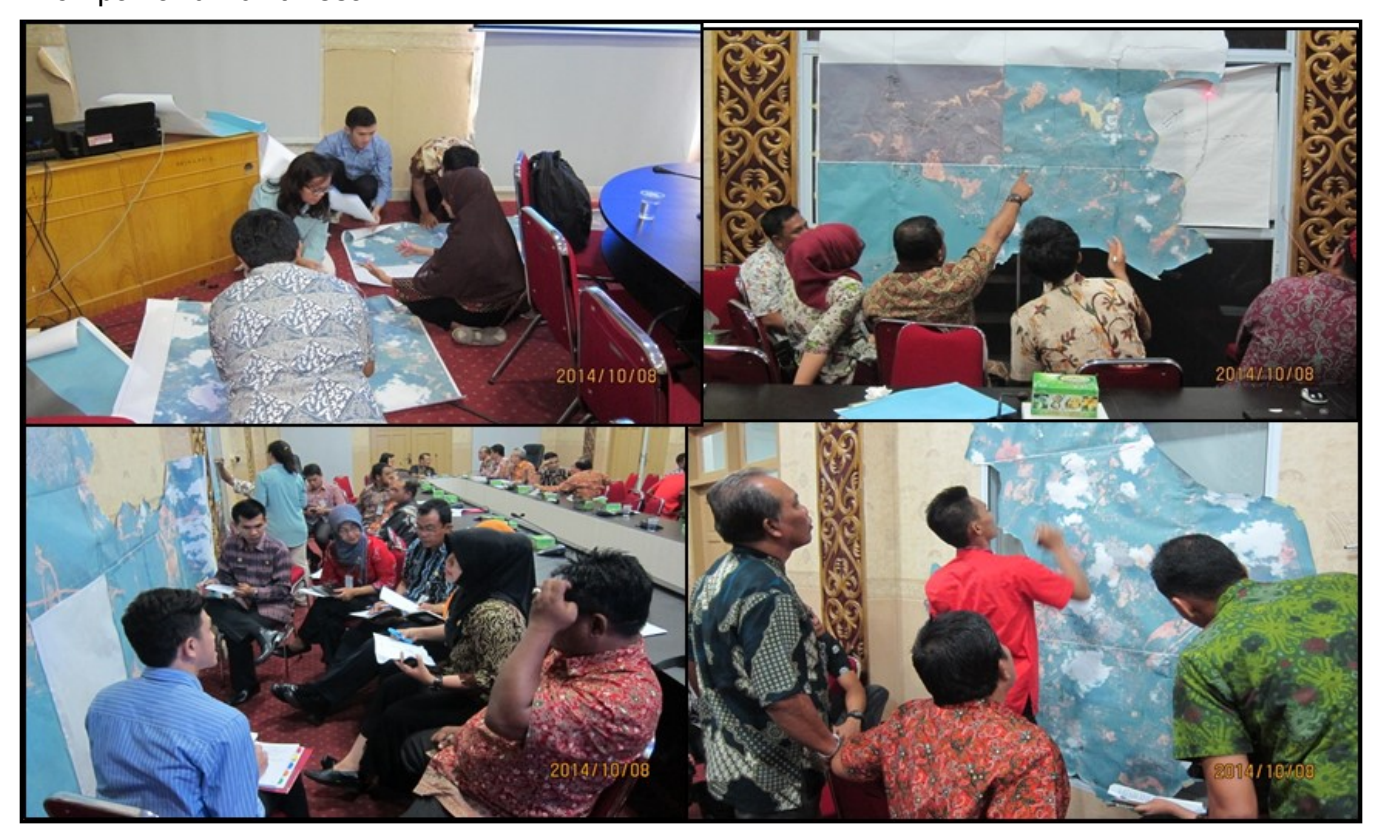

Fig.3 - Participatory mapping and FGD with stakeholders

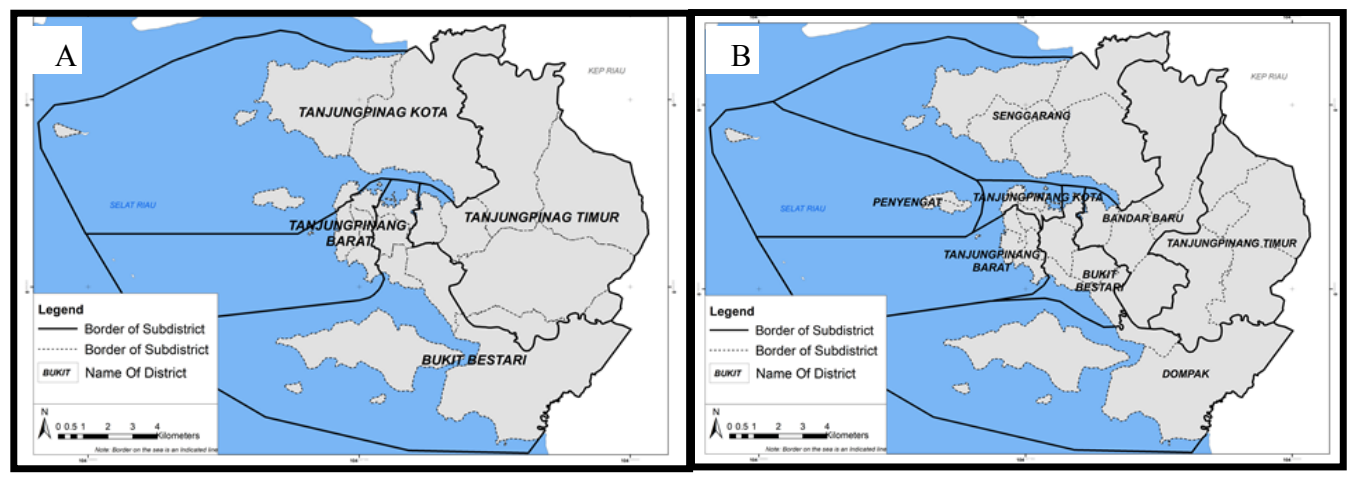

Fig. 4 - The changes in district delineation: A. Current district delineation, B. Delineation based on the Mayoral Decree No. 45/2010

Source: 1. Quickbird imagery for Tanjung Pinang City in 2008; 2. Goverment Regulation No.19/2008, on District; 3. Proposal for district division 2010, Tanjung Pinang City.

The Penyengat District records the lowest score (257), indicating that it is the only one in the incapable class (Table 3). On the other hand, three separate districts - Bandar Baru, Tanjung Pinang Timur and Bukit Besari - are classified as very capable. Such scores indicate major intra-city disparities and probably an imbalance in the development potential. Based on the gap to the average, the Penyengat Indra Sakti District has a large gap of over 100. It means that the mayor's proposed strategy is unlikely to significantly reduce the current inner-city 
disparities. Therefore, the national government should not legalize the decree on the new arrangement of districts in Tanjung Pinang City.

Table 3

Scoring outputs of proposed district delineation based on the Mayoral Decree No. $45 / 2010$

\begin{tabular}{|c|l|c|c|r|}
\hline No & Name of District & $\begin{array}{c}\text { Final } \\
\text { Score }\end{array}$ & Category & Gap to the average \\
\hline 1 & Tanjung Pinang Kota & 354 & Capable & -36.9 \\
\hline 2 & Penyengat Indra Sakti & 257 & Incapable & -133.9 \\
\hline 3 & Bandar Baru & 489 & Very capable & 98.1 \\
\hline 4 & Tanjung Pinang Timur & 457 & Very capable & 66.1 \\
\hline 5 & Senggarang & 402 & Capable & 11.1 \\
\hline 6 & Tanjung Pinang Barat & 398 & Capable & 3.1 \\
\hline 7 & Bukit Bestari & 423 & Very capable & -43.1 \\
\hline 8 & Dompak & 347 & Capable & \\
\hline
\end{tabular}

Since the decree has failed to fulfill the requirement of reducing the imbalance in the development outputs or inner-city disparities, a new district delineation is needed using the methods already described. The benefit of using FGD lay in the building of common understanding among stakeholders and, to some extent, the creation of consensus among them. Figure 5 illustrates a sample of key opinions used in delineating the district boundaries.

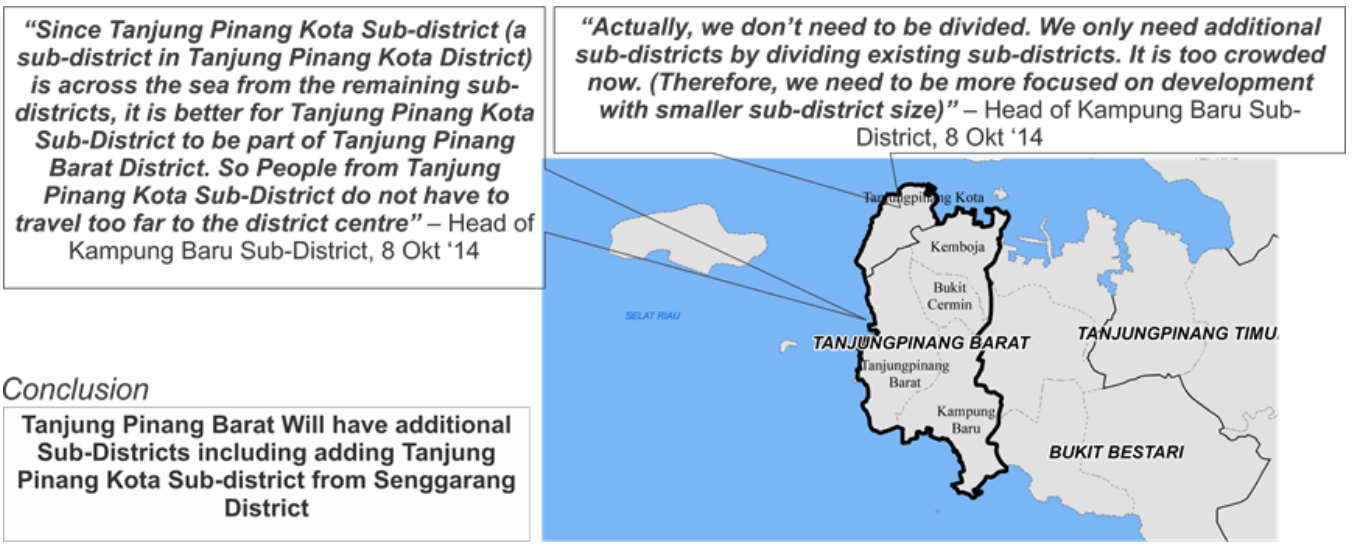

A. Discussion on Tanjung Pinang Barat District

Fig.5 - Key Findings of the participatory mapping and FGD in proposing the new district arrangement 
"So, eehh 5 sub-district become 10 subdistrict. Kampung Bulang Sub-district will be divided into 2 sub-district. Then, Kota Piring (changes) into 2, Batu Sembilan (change) into 3, Plang Kencana (change) into 3". - Head of Tanjung Pinang Timur SubDistrict, 8 Okt '14

\section{Conclusion}

Tanjung Pinang Timur District can be divided into 2 districts since it will have 10 sub-district. Air Raja and Batu Sembilan can be the district centres for the new 2 districts after the division of Tanjung Pinang Timur "On average, most habitants work in Air Raja and Batu Sembilan
District". - Head of Tanjung Pinang Timur District, 8 Okt "14

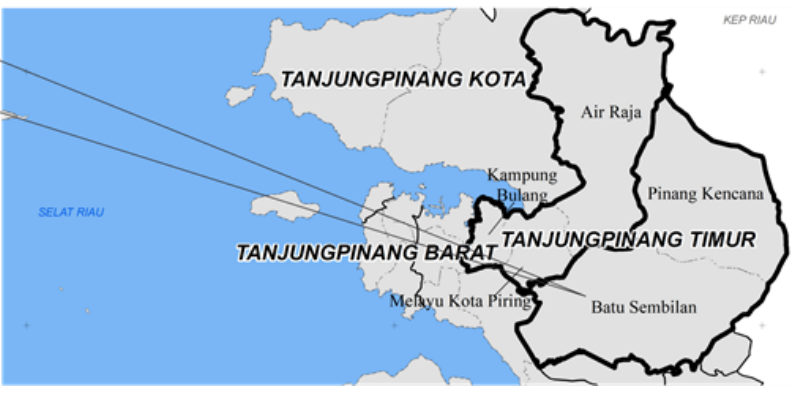

B. Discussion on Tanjung Pinang Timur District.

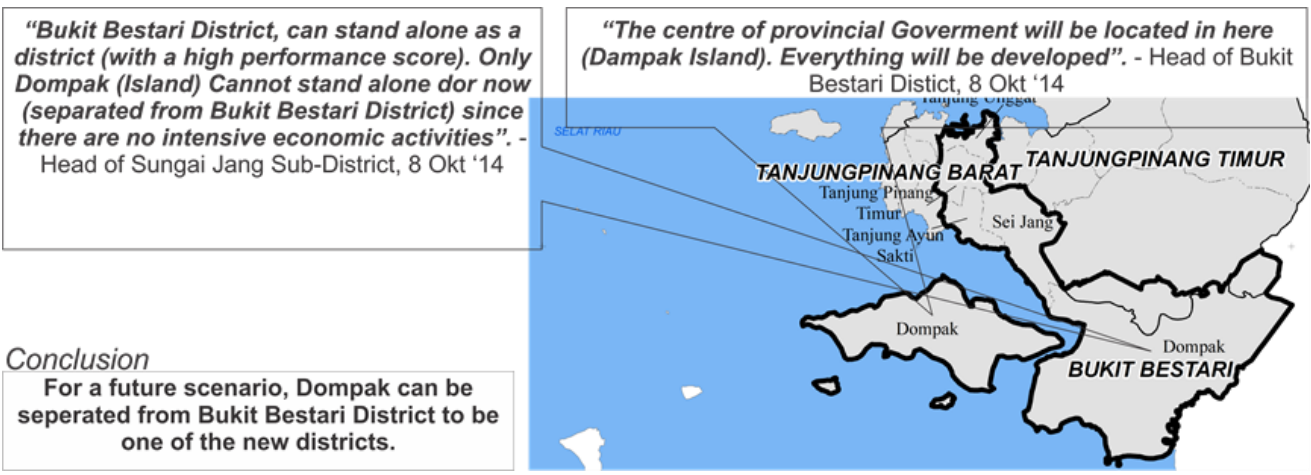

\section{Discussion on Bukit Bestari District}

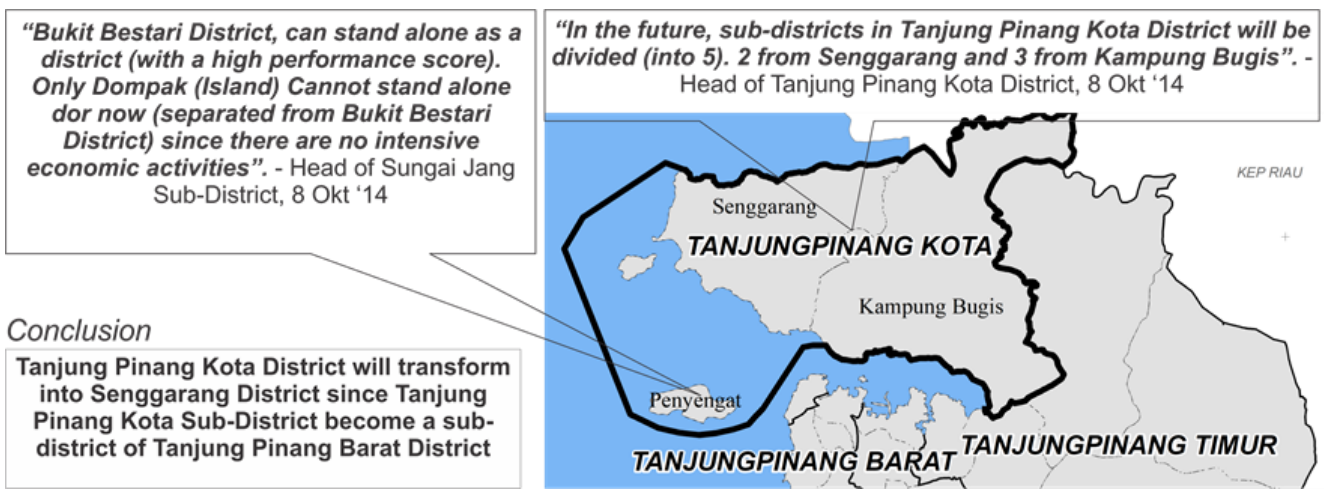

D. Discussion on Tanjung Pinang Kota District

Fig. 5 - Key Findings of the participatory mapping and FGD in proposing the new district arrangement 
In Figure 5A, stakeholders illustrate a more considered allocation process by dividing subdistricts into smaller sub-districts in the Tanjung Pinang Barat District. A key issue in the Tanjung Pinang Kota District is the location of the sub-district where the regional capital is located. It is separated from other sub-districts since it is located on an island. In addition, this sub-district is close to the Tanjung Pinang Barat District and it is therefore more accessible for people in Tanjung Pinang Barat than those from other sub-districts in Tanjung Pinang Kota, such as Senggarang and Kampong Bugis. Consequently, we recommend that the Tanjung Pinang Kota Sub-district should be part of Tanjung Pinang Barat District. We also recommend that the government divide the sub-districts of Tanjung Pinang Barat into smaller sized subdistricts than it is the case now. Moreover, the Penyengat Sub-district comprises several islands and it has a close relationship with the Tanjung Pinang Kota Sub-district and the other sub-districts in Tanjung Pinang Barat. The seaport connection among them is closer than the connection between the seaports in Penyengat and Senggarang. Therefore, the Penyengat Sub-district is more suitably part of Tanjung Pinang Barat rather than Tanjung Pinang Kota.

In Figure 5B, the FGD agreed that the Tanjung Pinang Timur District, reflecting the earlier discussion in 2009, should be divided into two districts: Bandar Baru and Tanjung Pinang Timur. These two new districts have different engines of economic growth. The Bandar Baru District will have the Bintan Centre, which is located in the Air Raja Sub-district as its commercial area and engine of economic growth. On the other hand, the Tanjung Pinang Timur District will still prosper with the new delineation since it contains the Batu Sembilan Subdistrict where a commercial area has been developed. In addition, a new airport in the Pinang Kencana Sub-district should lead to the development of new residential areas within it.

In Figure 5C, it is also proposed to divide the Bukit Bestari District into two parts: Bukit Bestari and Dompak. Up to now, Dompak, a separated island, has been a sub-district of the Bukit Bestari District. The new capital of Riau Islands Province will be located on this island, which is expected to experience accelerated future development and the stakeholders therefore agreed to propose it as a new district.

Finally, in Figure 5D, the Tanjung Pinang Kota District will lose the current Sub-district of the same name. To meet the required number of sub-districts in a district, it is suggested that both the Senggarang and Kampung Bugis Sub-districts be sub-divided. Thus the revised Tanjung Pinang Kota District will comprise two sub-districts from Senggarang and three from Kampung Bugis, giving it the required number of 5 . Since Tanjung Pinang Kota Sub-district becomes part of the Tanjung Pinang Barat District, it is recommended that the latter name be changed to Senggarang District. Figure 6 indicates the result of district delineation based on the participatory mapping - again using notional sub-district boundaries.

Table 4

Scoring outputs on proposed district delineation based on the participatory mapping

\begin{tabular}{|c|l|c|c|c|}
\hline No & Name of District & Final Score & Category & Gap to average \\
\hline 1 & Senggarang & 355 & Capable & -35.9 \\
\hline 2 & Tanjung Pinang Barat & 388 & Capable & -2.9 \\
\hline 3 & Air Raja & 453 & Very capable & 62.1 \\
\hline 4 & Tanjung Pinang Timur & 439 & Very capable & 48.1 \\
\hline 5 & Bukit Bestari & 444 & Very capable & 53.1 \\
\hline 6 & Dompak & 272 & Incapable & -118.9 \\
\hline \multicolumn{2}{|c|}{ Average } & 392 & & \\
\hline
\end{tabular}

In the new arrangement based on participatory mapping, the number of districts decreases from eight, as set by the government decree of 2010, to six. Using the previous scoring process 
for calculating the performance of the six new districts yielded the results displayed in Table 4 . The Dompak District has a low score of 272 , which demotes it to the incapable category. The large gap from the average for Dompak District (a score of over -100) indicates a high inner-city disparity. Therefore, the district re-arrangement based on participatory mapping and FGD does not qualify for the central government approval since there is still one district that is less than 340.

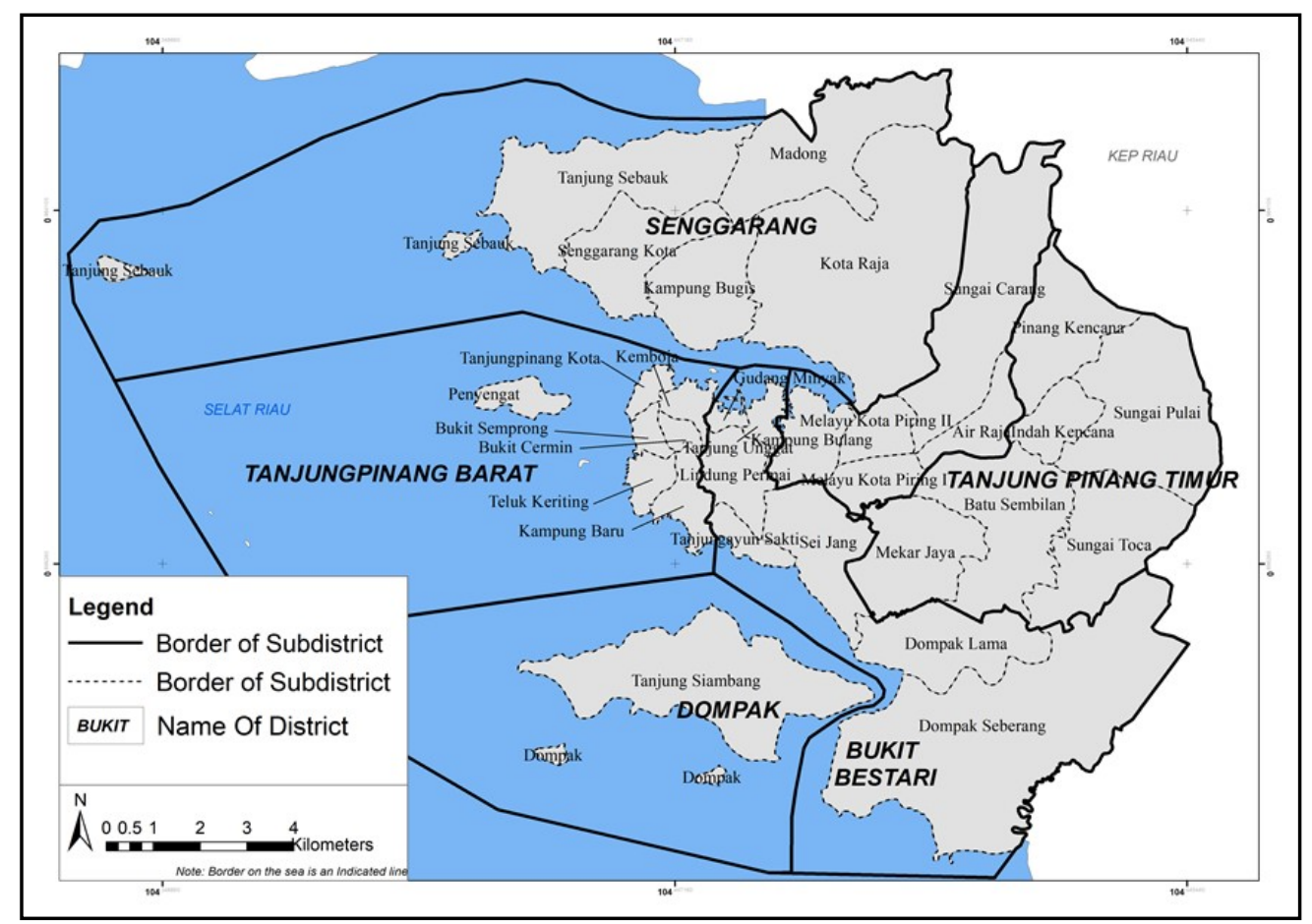

Fig. 6 - District boundaries based on participatory mapping

Source: 1. Quickbird imagery for Tanjung Pinang City in 2008; 2. Goverment Regulation No.19/2008, on District; 3. Proposal for district division 2010, Tanjung Pinang City.

Although the output of participatory mapping and FGD in un-implementable, it is still valuable as an input for the next analysis, particularly for the Dompak Sub-district. The analysis will elaborate stakeholders' narrations from participatory mapping via FGD, especially information on Bukit Bestari District and its sub-districts. Understanding the information from the stakeholders can uncover insights on stakeholders' aspirations and reveal other possibilities for administrative boundaries. Key information on the Bukit Bestari District and its sub-districts is as follows:

1. Since the Dompak Sub-district is still underdeveloped, the dependency of its activities on the main island is still high. All public services and commercial activities in Dompak are dependent on the Dompak Seberang Sub-district. The bridge connecting Dompak Island to the main island increases the dependency and interaction between them. Therefore, Dompak Island should be one of the sub-districts of a district on the main island until it is more developed.

2. In the Bukit Bestari District, most sub-districts, apart from the Dompak Sub-district, perform sufficiently well to become the new district centre. Some of them accommodate 
recent spill-over development from Tanjung Unggat, which has such major facilities as a Sekolah Tinggi IImu Sosial dan IImu Politik (STISIPOL = Social and Political Science Institute), Sekolah Tinggi IImu Kesehatan (STIKES = Health Science Institute), a mini golf course, hotels, the Ramayana Shopping mall, a seaport, and a big market. If the Dompak Sub-district is included in this district, its score will be higher than 444 . This is the score for Bukit Bestari District plus Dompak Island. A score of 444 is classified as very capable. It is much higher than the minimum capable score of 340 . Consequently, Bukit Bestari and Dompak Island should be divided into two districts, i.e. Bukit Bestari District with new delineation and Dompak District.

3. For the Dompak District to have an adequate score, Dompak Island cannot stand alone such as in Table 4 and Figure 6. We therefore suggest that the Dompak Lama and Dompak Seberang Sub-districts join Dompak Island to become the Dompak District, which also accommodates the stakeholders' comments as in point 1 above. Since the proposal includes only three sub-districts, both Dompak and Dompak Seberang SubDistricts will be divided into 2 sub-districts (Dompak Seberang Sub-district and Tanjung Siambang Sub-district). The revised score for this arrangement is 342 , which is classified as capable, meaning that the new delineation of Dompak District is acceptable.

4. Based on point 3, the number of sub-districts in Bukit Bestari District will decrease from eight to six, which is still allowable in terms of the minimum number of sub-districts and it scores 386 , indicating a capable district.

5. In terms of scores, the final output for every district falls in the capable and very capable categories and Table 5 clarifies that they all pass the minimum requirement to be legalized as new district arrangements. In terms of the gap from the average, a gap of less than 50 indicates a relatively low level of intra-city disparity. This arrangement also shows the highest average score compared to the previous two district arrangements. Nevertheless, both Dompak and Senggarang Districts still require a special focus on future development strategies. Both districts have gaps of around 50 below average and appropriate development strategies for them can reduce their economic and social disadvantage.

Final District Arrangement

Table 5

\begin{tabular}{|c|l|c|c|r|}
\hline No & Name of District & Final Score & Category & Gap to average \\
\hline 1 & Senggarang & 355 & Capable & -35.9 \\
\hline 2 & Tanjung Pinang Barat & 385 & Capable & -5.9 \\
\hline 3 & Bandar Baru & 453 & Very capable & 62.1 \\
\hline 4 & Tanjung Pinang Timur & 446 & Very capable & -45.1 \\
\hline 5 & Bukit Bestari & 386 & Capable & -48.9 \\
\hline 6 & Dompak & 342 & Capable & \\
\hline \multicolumn{2}{|c|}{ Average } & 395 & & \\
\hline
\end{tabular}

Based on the above information, Figure 7 shows the new district delineation. It also illustrates the changes in delineation created by participatory mapping (PM) and FGD and the final output compared to the 2010 decree. In the final output, the districts of Tanjung Pinang City are Senggarang, Bandar Baru, Tanjung Pinang Barat, Bukit Bestari, Tanjung Pinang Timur, and Dompak. Table 6 lists the final arrangement of sub-districts. 

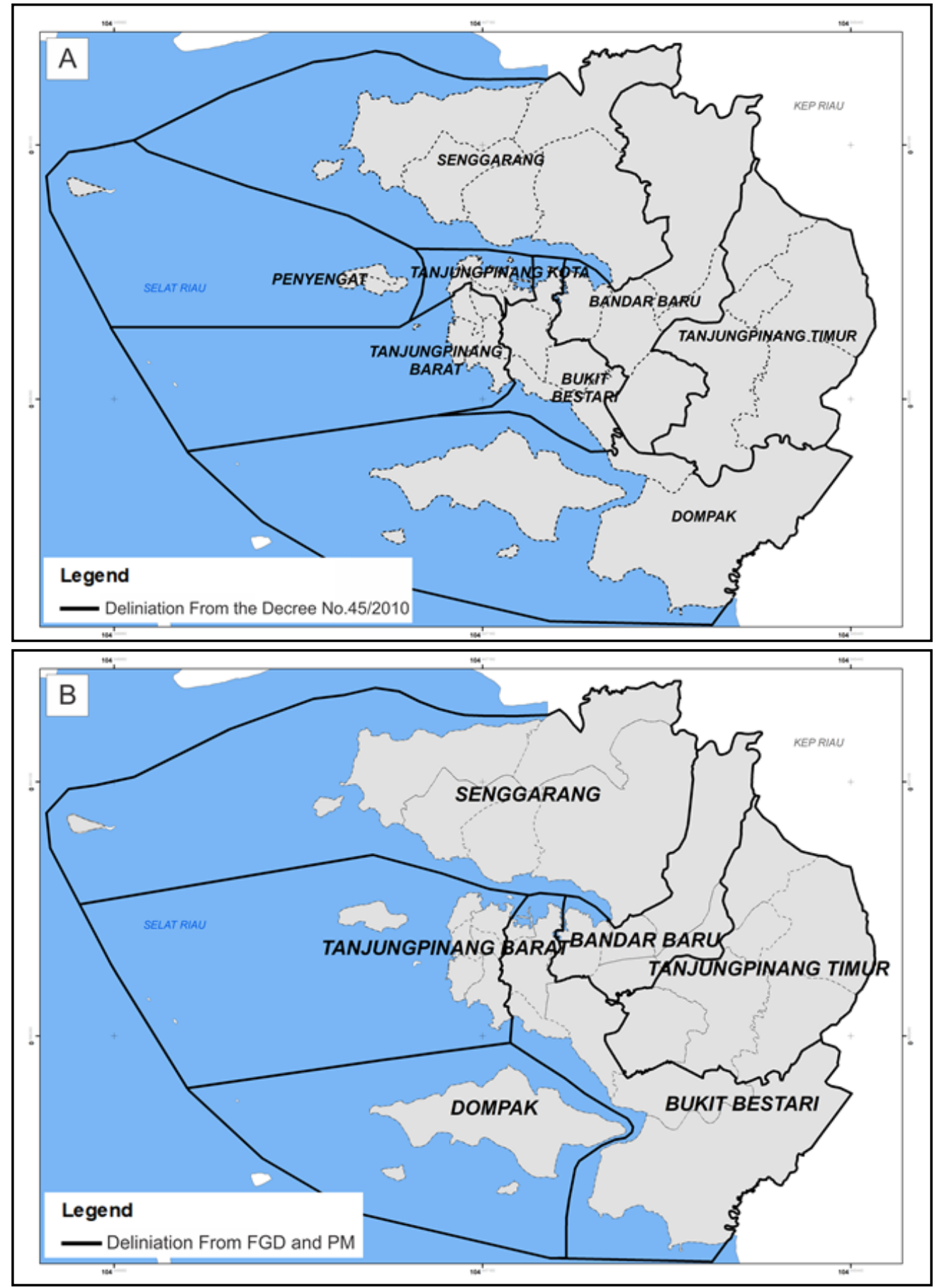


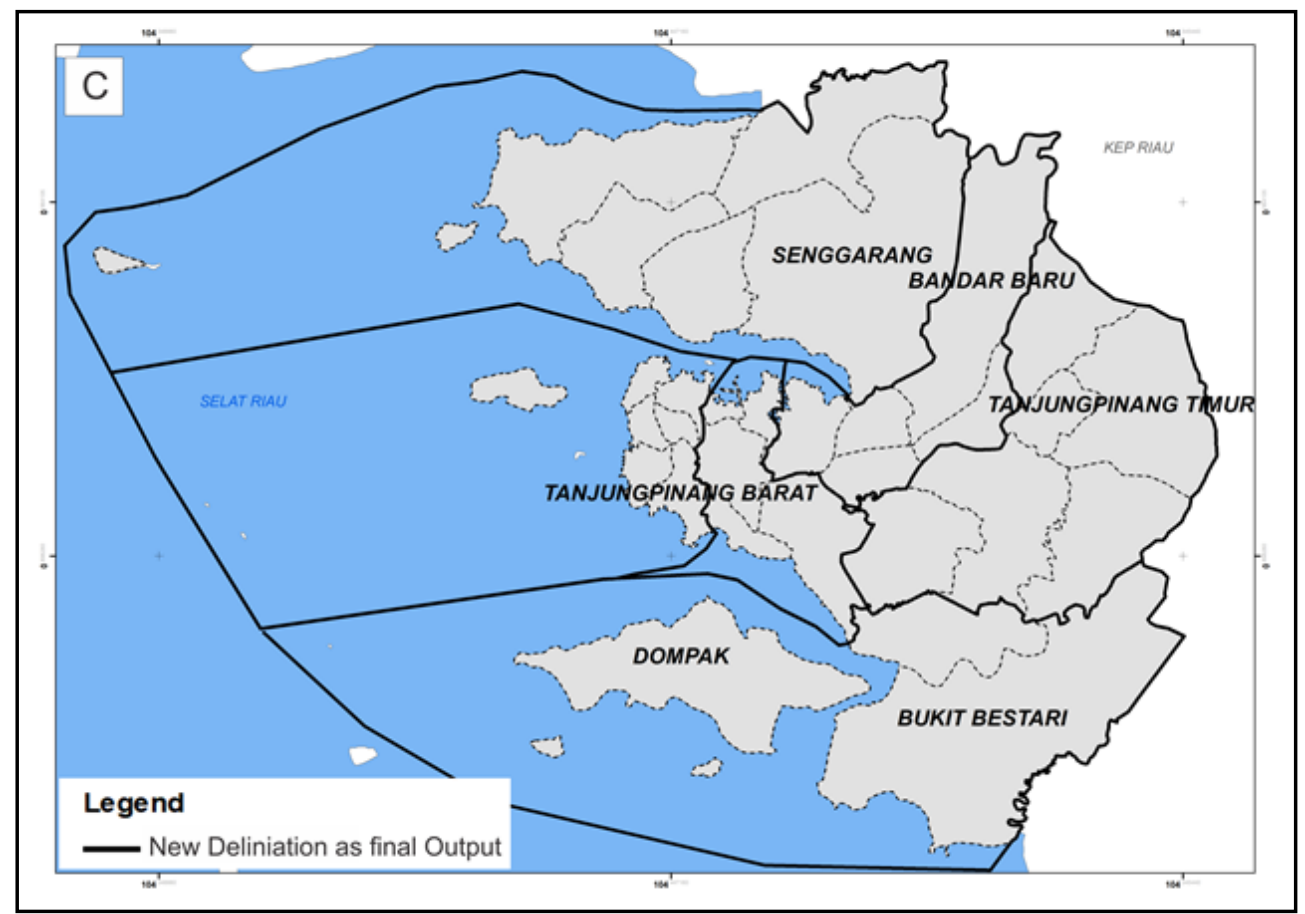

Fig.7 - Transformation of Proposed District Delineation:

A. Mayoral decree delineation; B. Delineation based on FGD and PM; C. Final proposed delineation

Final Proposed Districts and Sub-districts

Table 6

\begin{tabular}{|c|l|l|}
\hline No & Name of District & \multicolumn{1}{c|}{ Name of Sub-districts } \\
\hline 1 & Senggarang & $\begin{array}{l}\text { Sebauk, Senggarang Kota, Kampung Bugis, Kota Raja, Ma- } \\
\text { dong. }\end{array}$ \\
\hline 2 & $\begin{array}{l}\text { Tanjung Pinang } \\
\text { Barat }\end{array}$ & $\begin{array}{l}\text { Tanjung Pinang Kota, Kemboja, Bukit Semprong, Bukit Cer- } \\
\text { min, Teluk Keriting, Kampung Baru, Penyengat. }\end{array}$ \\
\hline 3 & Bandar Baru & $\begin{array}{l}\text { Sungai Carang, Air Raja, Melayu Kota Piring 1, Melayu Kota } \\
\text { Piring 2, Kampung Bulang. }\end{array}$ \\
\hline 4 & $\begin{array}{l}\text { Tanjung Pinang } \\
\text { Timur }\end{array}$ & $\begin{array}{l}\text { Pinang Kencana, Sungai Pulai, Kijang Kencana, Batu Sembi- } \\
\text { lan, Sungai Toca, Mekar Jaya. }\end{array}$ \\
\hline 5 & Bukit Bestari & $\begin{array}{l}\text { Gudang Minyak, Tanjung Unggat, Lindung Permai, Sei Jang, } \\
\text { Tanjungayun Sakti. }\end{array}$ \\
\hline 6 & Dompak & $\begin{array}{l}\text { Dompak 1, Dompak 2, Dompak Lama, Dompak Seberang 2, } \\
\text { Tanjung Siambang. }\end{array}$ \\
\hline
\end{tabular}

In implementing the proposed district arrangement, four main development strategies should be carried out. These key development strategies indicate the new pattern of development in 
Tanjung Pinang City, especially for the Dompak and Senggarang Districts, which have the two lowest scores. The strategies are:

1. Enhance the multiplier effect of a new provincial capital city on Dompak Island. The newly designated areas for the provincial capital on Dompak Island will boost the island's development. Many cities in Indonesia have benefitted from their administrative function, including Jakarta, Surabaya and Medan. The new capital city will also receive investment in public facilities, but one of the main challenges will be to leverage private investment on the back of public expenditure. The zoning of industrial areas in the Seberang Sub-district might have significant advantages due to its proximity to the capital city. Therefore, the multiplier effects of administrative activities in the Dompak Island can be increased by improving the connection of industrial areas to the capital as well as to such major infrastructure items as the airport and seaport. Furthermore, most administrative cities require residential areas and other residential supporting facilities. The multiplier effect of the capital city can also be stimulated via large-scale residential areas.

2. Accelerate sub-district division in Senggarang District to stimulate the development process. After losing the Tanjung Pinang Kota and Penyengat Sub-districts, Senggarang requires additional sub-districts to reach the minimum of five sub-districts in order to be able to implement the new district arrangement. The opportunity to increase the number of sub-districts is high since the municipal capital city of Tanjung Pinang City will be moved to the Senggarang District. Setting up the new municipal capital city can attract other investments for development from both public and private parties. Therefore, the Tanjung Pinang City Government has to focus on providing appropriate and supportive regulations to accelerate the development of the municipal capital city and sub-district division in Senggarang District. To some extent, the city government also needs to provide some funds for developing public facilities in Senggarang to be 'the frontier' of development. In the Indonesian context, the administrative status of a region can make an important contribution to its prosperity, and the higher its administrative status the more likely it is to receive investment in public infrastructure, which will in turn stimulate more investment both from public and private parties.

3. Provide adequate public services, particularly for the Penyengat Sub-district, which performs poorly in terms of public facilities. It consists of some small islands and it requires infrastructure investment to connect them with the main island and district center. Strong government investment in public facilities is critical to trigger the region's economic development, perhaps utilizing environmental and cultural tourism activities to both stimulate the output and to reduce intra-city disparities.

4. Develop the areas surrounding the new airport in the Pinang Kencana Sub-district. This major infrastructure facility can boost the surrounding development. Many cases of development have shown the economic potential of airports, called aero-city and Tanjung Pinang City can follow suit.

\section{Conclusion}

By using the ideas of stakeholders through a process of participatory mapping via FGD and scoring district performance across a range of variables, six districts were delimited for Tanjung Pinang City: Senggarang, Tanjung Pinang Barat, Bandar Baru, Tanjung Pinang Timur, Bukit Bestari and Dompak. All districts' boundaries are modified for a more balanced development performance.

Furthermore, Dompak Island and the Senggarang District have a special opportunity to plan the major infrastructure development necessary to sustain their respective roles as provincial 
and municipal capital cities. The Pinang Kencana Sub-district's new airport also provides an opportunity to boost local development in its jurisdiction. Moreover, Penyengat Island should focus on infrastructure development to ensure that other development processes in Tanjung Pinang City will not marginalize the island. These development strategies can assist in the reduction of the intra-city disparities. Furthermore, as part of network cities, the specialty in every districts and infrastructures development can increase connectedness among the districts. Those connected districts will also balance and improve the development outputs.

In line with the district arrangement procedure in the Government Regulation No. 19/2008, the district re-arrangement process above was unable to provide the optimal solution, particularly in reducing intra--city disparities. A combination between the scoring process and participatory mapping via FGD has given substantial insights into district and sub-district interactions. The combination technique can also optimize all potential solutions and assess iteratively the predicted outputs of all potential solutions. Within this calculation, the re-arrangement of district and sub-district delineation can also contribute to decreasing intra-city disparity. Therefore, this combination technique is very suitable for district boundaries rearrangement as part of a development strategy. This combination technique should be applied in the Indonesian formal regulation of districts (or any administrative boundaries) delineation process.

\section{Acknowledgements}

The author expresses his gratitude to the Tanjung Pinang City Government for inviting all stakeholders both in data collection and in confirming the outputs of analysis. This project has also been a collaboration between Tanjung Pinang City Government and ITS (Institut Teknologi Sepuluh Nopember, Surabaya).

\section{References}

ANDERSSON K., BENAVIDES J. P., LEÓN R. (2014), Institutional diversity and local forest governance, Environmental Science \& Policy 36, 61-72.

BAILEY N., TUROK I. (2001), Central Scotland as a Polycentric Urban Region: Useful Planning Concept or Chimera?, Urban Studies 38 (4), 697-715.

BAMBERGER M., TARSILLA M., HESSE-BIBER S. (2016), Why so many "rigorous" evaluations fail to identify unintended consequences of development programs: How mixed methods can contribute, Evaluation and Program Planning 55, 155-162.

BATTEN D. F. (1995), Network Cities: Creative Urban Agglomerations for the $21^{\text {st }}$ Century, Urban Studies 32 (2), 313-327.

BERGER T., ENFLO K. (2017), Locomotives of local growth: The short- and long-term impact of railroads in Sweden, Journal of Urban Economics 98, 124-138.

DAWKINS C. J. (2003), Regional Development Theory: Conceptual Foundations, Classic Works, and Recent Developments, Journal of Planning Literature 18 (2), 131-172.

FIRDAUS S. (2017), Ketimpangan pembangunan (Development disparities), Republika 30.03.2017, Retrieved from: www.republika.co.id.

GAIGNÉ C., RIOU S., THISSE J.-F. (2016), How to make the metropolitan area work? Neither big government, nor laissez faire, Journal of Public Economics 134, 100-113.

GLASSON J. (1974), An introduction to regional planning: Concepts, Theory And Practice, Hutchinson, London.

GIANG D. T. H., PHENG L. S. (2011), Role of construction in economi development: Review of key concepts in the past 40 years, Habitat International 35 (1), 118-125.

GRUBY R. L., BASURTO X. (2013), Multi-level governance for large marine commons: politics and polycentricity in Palau's protected area network, Environmental Science \& Policy 33, 260-272. 
KAN K. (2016), The transformation of the village collective in urbanising China: $A$ historical institutional analysis, Journal of Rural Studies 47 Part B, 588-600.

KEMENDAGRI (2013), Daerah Otonom Baru di Indonesia Per Provinsi Tahun 19992013, Ministry of Home Affairs, Retrieved from: www.otda.kemendagri.go.id.

MEIJERING L., WEITKAMP G. (2016), Numbers and narratives: Developing a mixedmethods approach to understand mobility in later life, Social Science \& Medicine 168, 200-206. MIYOSHI T. (1997), Successes and failures associated with the growth pole strategies, University of Manchester, Retrieved from: miyotchi.tripod.com/dissert.htm.

MEIJERS E. J., ROMEIN A., HOPPENBROUWER E. C. (2003), Planning polycentric urban regions in North West Europe. Value, feasibility and design, Delft University Press, Delft. MYRDAL G. (1957), Economic theory and underdeveloped regions, Duckworth, London.

RICHARDSON H. W., RICHARDSON M. (1975), The relevance of growth center strategies to Latin America, Economic Geography 51 (2), 163-178.

SALVATI L., VENANZONI G., CARLUCCI M. (2016), Towards (spatially) unbalanced development? A joint assessment of regional disparities in socioeconomic and territorial variables in Italy, Land Use Policy 51, 229-235.

STEWART M., MAKWARIMBA E., BARNFATHER A., LETOURNEAU N., NEUFELD A. (2008), Researching reducing health disparities: Mixed-methods approaches 66 (6), 14061417.

STRICKLAND-MUNRO J., KOBRYN H., BROWN G., MOORE S. A. (2016), Marine spatial planning for the future: Using Public Participation GIS (PPGIS) to inform the human dimension for large marine parks, Marine Policy 73, 15-26.

TODARO M. P. (1981), Economic Development in the Third World, Longman, London.

YANG F., ZHANG D., SUN C. (2016), China's regional balanced development based on the investment in power grid infrastructure, Renewable and Sustainable Energy Reviews $53,1549-1557$.

ZENG S. X., MA H. Y., LIN H., ZENG R. C., TAM V. W. Y. (2015), Social responsibility of major infrastructure projects in China, International Journal of Project Management 33 (3), 537-548.

ZUINDEAU B. (2007), Territorial Equity and Sustainable Development, Environmental Values $16(2), 253-268$.

Initial submission: 01.11.2016

Revised submission: 20.09.2017

Final acceptance: 27.10 .2017

Correspondence: Faculty of Civil Engineering and Planning, ITS Surabaya, Kampus ITS, Sukolilo, Surabaya 60111, Jawa Timur, Indonesia.

Email: adjie@urplan.its.ac.id 